\title{
Increase in antifungal activity by the combination of tolaasin and its analogue peptides
}

\author{
Yeong-Bae Yun ${ }^{1}$ (I) $\cdot$ Hyoung-Jin Lee ${ }^{1}$ (I) $\cdot$ Young-Kee Kim $^{1}$ (C) \\ 톨라신류 펩티드 흔합처리에 의한 항진균 활성의 증가
}

윤영배 ${ }^{1} \cdot$ 이형진 ${ }^{1} \cdot$ 김영기 $^{1}$

Received: 12 February 2018 / Accepted: 22 February 2018 / Published Online: 31 March 2018

(C) The Korean Society for Applied Biological Chemistry 2018

\begin{abstract}
Oak mushroom (Lentinus edodes) is cultivated by using oak logs and sawdust medium. Green mold (Trichoderma) infection on these media severely suppresses the growth of oak mushroom. Usages of antibiotics and chemicals are not generally allowed to control of green mold since the mushroom is a fresh food. Tolaasin and its analogues, peptide toxins secreted by Pseudomonas tolaasii, have the antifungal activity and they have been successful to control the green mold disease. When the green mold, Trichoderma harzianum $\mathrm{H} 1$, was cultured in the presence of these toxins, the growth of fungus was effectively suppressed. In sawdust media, when the bacterial culture supernatants were sprayed on the aerial hyphae of green molds, the fungal growth was completely suppressed. Particularly, the antifungal activity was greatly increased by the combined culture extracts of $P$. tolaasii 6264 and HK11 strains. Therefore, these bacterial strains and their peptide toxins were able to suppress the growth of green molds and these can be good candidates to prevent from Trichoderma disease in oak mushroom cultivation.
\end{abstract}

Keywords Antifungal peptide · Green mold disease · Oak mushroom · Synergic effect $\cdot$ Trichoderma harzianum

Young-Kee $\operatorname{Kim}(\triangle)$

E-mail: ykkim10@cbnu.ac.kr

${ }^{1}$ Department of Environmental and Biological Chemistry, Chungbuk National University, Cheongju, Chungbuk 28644, Republic of Korea

This is an Open Access article distributed under the terms of the Creative Commons Attribution Non-Commercial License (http://creativecommons. org/licenses/by-nc/3.0/) which permits unrestricted non-commercial use, distribution, and reproduction in any medium, provided the original work is properly cited.

\section{서 론}

표고버섯(Lentinus edodes)은 독특한 맛과 당질, 단백질, 비타민, 무기질과 같은 영양소를 골고루 함유하고 있어 고급 식재료로 사용되고 있다(Ota 1984). 또한, 표고버섯은 항암 작용 및 혈중 콜레스테롤 저하 등에 효과가 있음이 밝혀져 유효성분 등에 대 한 많은 연구가 진행되고 있다. Chihara 등(1970)은 표고버섯의 자실체로부터 항암활성을 갖는 다당체 lentinan을 분리 및 정제 하였으며, lentinan은 현재 항암보조제로 시판되고 있다(Fujii 등, 1978). 1990년대 이후 식생활 향상에 따라 버섯의 수요가 증가 하면서 표고버섯의 생산량이 크게 증가하였으나, 2000년대 후 반기를 정점으로 감소하는 경향을 보이고 있다(Korea Rural Economic Institute 2014). 국내에서 생산이 감소한 물량은 중국 등으로부터 수입하여 충당하고 있으며, 수입량은 점차 증가하여 2014년에 총 수요량의 약 $37 \%$ 에 도달하였다. 현재에도 표고버 섯의 수요량에 비하여 농가에서의 공급량은 부족한 실정이다.

국내 표고버섯 생산량의 감소는 여러 가지 원인에 의해 발생 하나, 특히 푸른곰팡이병(green mold disease)의 빈번한 발생이 주요 원인 중의 하나이다. 푸른곰팡이병은 인공재배를 하는 모 든 버섯에서 발생하며, 균사는 백색을 띠지만 점차 포자를 형 성하면서 푸른색을 띠게 된다. 톱밥배지나 원목에 푸른곰팡이 (Trichoderma)가 감염되면 목재를 부패시키고, 표고균사와 경합 하면서 gliotoxin이라는 독소를 분비하여 표고균사의 생장과 버 섯 발이를 억제한다(Brian과 Hemming 1945; Seaby 1998; Ait-Lahsen 등, 2001). 이러한 Trichoderma에 의한 피해는 국내 뿐만 아니라 외국에서도 보고되고 있으며, 표고버섯 생산량이 많은 일본이나 중국, 유럽, 이란, 미국 등에서도 푸른곰팡이에 의한 피해가 빈번히 나타나고 있다(Komon-Zelazowska 등, 2007). 버섯은 신선식품으로 푸른곰팡이병을 방제하기 위한 항 생제나 농약 등의 화학물질 사용이 엄격히 제한되어 있다. 항 생제 등의 화학물질을 처리할 경우에 내성균이 발생할 가능성 
이 있으며, 표고균사 등 다른 생물에 대한 독성도 문제를 유발 한다(Lee 등, 2009). 따라서, 독성이 작고 쉽게 분해되는 소수 의 제한된 약제를 사용할 수 있으나, 그것도 버섯이 발생하기 전에 목재나 배지에만 사용이 허용된다.

이전 연구에서는 갈반병 원인 균주 Pseudomonas tolaasii가 분비하는 톨라신과 톨라신류의 펩티드가 푸른곰팡이 Trichoderma harzianum $\mathrm{H} 1$ 균주를 효과적으로 사멸시켜 이들의 뛰어난 항 진균 활성을 확인하였다(Lee 등, 2017). 더욱이 톨라신류 펩티 드는 표고버섯의 균사에는 피해를 주지 않아 푸른곰팡이의 방 제에 선택성이 매우 높았다(Cho 등, 2007b). 본 연구에서는 표 고버섯 재배사에서 빈번하게 발생하는 푸른곰팡이의 실용적 방 제방안 마련을 위하여, 항진균 펩티드를 생산하는 다양한 $P$. tolaasii 변이균주들을 배양하고, 배양액을 혼합하여 처리하였을 때 항진균 활성의 상승효과를 조사하였다.

\section{재료 및 방법}

\section{항진균 펩티드 균주의 분리}

톨라신류 항진균 펩티드를 생산하는 Pseudomonas tolaasii 균주 들은 갈반병에 감염된 버섯으로부터 Cho 등(2000)의 방법에 따 라 분리하였다. 간략히, 병반이 형성된 버섯 조직을 멸균한 칼 로 잘라내어 균질한 다음 멸균수로 희석하였다. 희석액 $200 \mu \mathrm{L}$ 를 Pseudomonas agar F (PAF) 평판배지 위에 도말하고, 25 ${ }^{\circ} \mathrm{C}$ 에서 48 시간 배양하여 형광을 갖는 균주를 선별하고, 버섯조 직함몰검정법(pitting test)을 이용하여 병원성을 평가하였다( $\mathrm{Kim}$ 등, 1994). 분리한 균은 glycerol $20 \%$ 를 함유한 PAF 저장배지 $1.5 \mathrm{~mL}$ 에 저장하여 초저온냉동고 $\left(-70^{\circ} \mathrm{C}\right)$ 에 보관하며 사용하였다.

\section{푸른곰팡이의 분리}

푸른곰팡이는 버섯종균회사의 재배사나 표고버섯 재배농가에서 병이 발생한 톱밥배지를 얻어 푸른곰팡이가 발생한 부분 약 $1 \mathrm{~cm}^{2}$ 를 멸균한 칼로 잘라내어 $40 \mathrm{~mL}$ 멸균수에 넣고 분쇄한 후 면직포로 톱밥배지 및 불순물을 제거하였다. 이 혼합액을 멸균 수로 희석하여 Potato dextrose agar (PDA) 평판배지 위에 도 말하여 $27^{\circ} \mathrm{C}$ 에서 48-60시간 배양한 후, 형성된 colony를 분리 하였다. 분리한 균주는 다시 PDA 평판배지 위에 접종하여 4872시간 동안 배양하여 균주가 충분히 자란 후에 배지를 멸균수 $30 \mathrm{~mL}$ 에 넣어 현탁하고, 면직포에 여과하여 포자현탁액을 얻었 다. 포자는 $20 \%$ glycerol 수용액에 현탁하여 초저온냉동고(-70 $\left.{ }^{\circ} \mathrm{C}\right)$ 에 보관하였다. 모든 푸른곰팡이는 유전자 분석을 통하여 Trichoderma harzianum으로 동정되었고, 본 실험에서는 톱밥배 지에 T. harzianum $\mathrm{H1}$ 균주를 접종하여 사용하였다.

\section{톱밥배지에서 푸른곰팡이 발생면적 측정}

톱밥배지에서 항진균 펩티드 생성 균주 배양액의 항진균 활성 을 측정하기 위하여 곰팡이가 발생한 톱밥배지의 표면이 젖도 록 균주배양액을 1회 처리하였다. 균주배양액은 PAF 액체 배지 에 항진균 펩티드 생성 균주를 $1 \%(\mathrm{v} / \mathrm{v})$ 접종하여 배양한 후, 배양액을 원심분리하여 균체를 제거한 후 사용하였다. 얻어진 균주배양액 내의 항진균 펩티드의 농도는 용혈활성으로 약 1.5 $3 \mathrm{HU}$ (hemolytic unit)의 범위를 보였다. Lee 등(2017)의 색상
선택법을 이용하여 톱밥배지에서 푸른곰팡이의 발생면적을 평 가하였다. 간략히, 톱밥배지 전체를 사진으로 찍은 후 사진에서 푸른곰팡이의 색상을 컴퓨터로 분석하면 RGB (red, green, blue) 세 가지 색상으로 분석이 되며, 본 실험에서 사용한 푸른 곰팡이의 색상 범위는 R: $100-140, \mathrm{G}: 110-150, \mathrm{~B}: 110-150$ 의 값을 갖는다. 이러한 범위는 사진을 찍을 때의 날씨 또는 시간 에 따라 차이가 있기 때문에 약간의 변화를 주며 푸른곰팡이의 면적을 측정하였다. 분석방법은 Adobe Photoshop CS 프로그램 을 이용하여 위의 색상범위를 선택하고 푸른 색상범위의 색을 가지고 있는 면적이 표현이 되면, 이 면적의 픽셀수를 계산하 여 곰팡이의 발생면적의 변화를 측정하였다.

\section{결과 및 고찰}

\section{색상선택법에 의한 푸른곰팡이 발생면적 측정}

몇가지 P. tolaasii 변이균주가 생산하는 톨라신류의 세균성 펩 티드들은 항진균 활성을 갖고 있으며 표고버섯 재배에서 큰 피 해를 주고있는 푸른곰팡이를 억제할 수 있음이 확인되었다(Lee 등, 2017). 또한 Cho 등(2007b)은 톨라신류의 펩티드가 표고버 섯의 균사에는 영향이 없다고 보고하였으며, 본 연구에서 이 펩 티드들은 푸른곰팡이에 대한 살균효과가 처리 즉시 나타났고, 비가역적으로 균사조직을 파괴하였다. 따라서, 톨라신 및 유사 펩티드류들의 특성을 확립한다면 이들을 이용한 푸른곰팡이의 방제가 가능할 것이다. 한 균주의 배양액을 사용하는 경우에는 톨라신류 펩티드의 종류에 따라 또는 푸른곰팡이의 종에 따라 효과가 달라질 수 있고, 장기 사용시 항진균 활성에 저항성을 갖는 푸른곰팡이가 발생할 수 있다. 따라서, 푸른곰팡이의 종류 에 따른 적용성을 넓히고 저항성 곰팡이 균주의 발생확률을 감 소시키기 위하여, 2 가지 이상의 P. tolaasii 변이균주 배양액을 혼합한 후 항진균 효과를 측정하였다. 배양액의 혼합은 항진균 활성이 가장 우수한 P. tolaasii 6264와 HK2 균주, 활성이 높 으나 특성이 비교적 다른 P. tolaasii HK11와 HK23 균주를 선 택하여 수행하였다.

항진균 활성을 갖는 펩티드의 활성측정을 위해서는 표고버섯 배지에 감염된 푸른곰팡이의 양적변화를 평가하는 방법이 필요 하나 표고버섯과 푸른곰팡이의 균사가 혼재한 톱밥배지에서는 푸른곰팡이의 발생을 양적으로 측정하는 것이 매우 어렵다. 표 고버섯 톱밥배지는 버섯균사를 내부까지 충분히 배양한 후 갈 변시켰기 때문에 푸른곰팡이의 초기 오염은 배지의 표면에서만 일어난다. 본 연구에서는 톱밥배지 표면에서 푸른곰팡이 색의 면적을 측정하고 그 부분의 면적을 계산하는 방법인 '색상선택 법'으로 푸른곰팡이의 발생면적을 계산하였다(Lee 등, 2017). Fig. 1은 육안으로 푸른곰팡이 오염 정도가 다른 3 개의 배지를 촬영한 후, 색상선택법으로 사진을 스캔하여 배지 표면의 푸른 곰팡이 오염 부분을 아래에 검게 나타낸 것이다. 푸른곰팡이의 면적은 검은 부분의 픽셀수를 측정하여 계산하였고, 색상으로 선택된 부위는 육안으로 확인한 푸른곰팡이 면적이나 발생부위 와 잘 일치하였다.

\section{P. tolaasii 6264와 변이주의 항진균 효과}

항진균 활성의 효과는 곰팡이가 자란 톱밥배지 표면에 $P$. 

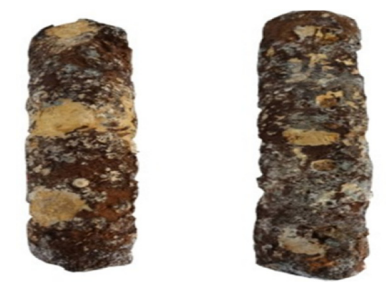

ת

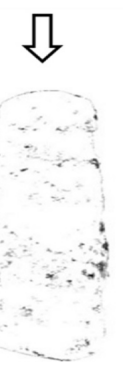

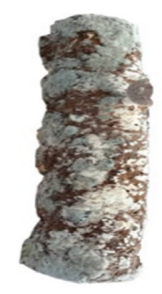

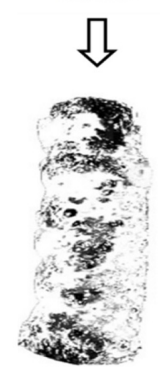

Fig. 1 Evaluation of the fungal growth area occupied by green molds. (Top) Three $\log$ media with different amount of mold growth were chosen. The area was analyzed by Color Selection Method, calculating the colored-area of fungal growth represented by the combination of RGB values, R; 100-140, G; 110-150, B; 110-150. (Below) The fungalgrown area analyzed was redrawn with black color. Thus, the black area on each $\log$ is representing the area of green molds

tolaasii 변이균주 배양액을 처리하고, 초기의 푸른곰팡이 발생 면적을 기준으로 2 일차와 6 일차에 촬영한 사진에서 푸른곰팡이 의 면적 변화를 비교하였다(Fig. 2). 톨라신류 펩티드를 처리하 지 않은 대조구 실험에서 푸른곰팡이는 생육을 계속하여 6일차 에는 배지 전체에 퍼져 면적이 증가하였다. 반면, P. tolaasii 6264 균주와 HK2, HK11, HK23을 각각 혼합하여 처리한 경우 에는 푸른곰팡이의 생육을 억제하여 푸른곰팡이의 면적은 크게 감소하였으며, 시간의 경과에 따른 푸른곰팡이의 생육증가는 전

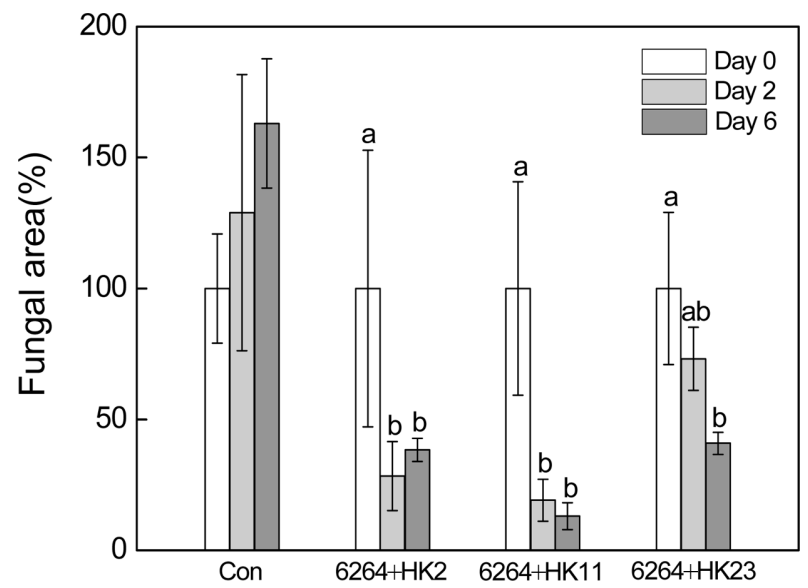

Fig. 3 Evaluation of the antifungal activities obtained by the culture mixtures of two different strains indicated. Data are mean \pm SE (bars) percentage of the results from three replicates. The same letters are not statistically significant at $p<0.05$ (Turkey's Test, SAS Version 9.4)

혀 관측되지 않았다. 우수한 항진균 효과는 6264 균주의 배양 액을 포함한 3 가지 조합 모두에서 관측하였다.

항진균 효과를 푸른곰팡이의 면적으로 평가하였을 때, 대조 구의 경우에는 푸른곰팡이의 발생 면적이 처리시작일과 비교하 여 2일차에는 약 1.3 배, 6일차에는 약 1.7배까지 증가하였다(Fig. 3). 반면, P. tolaasii 6264 균주와 HK2, HK11의 배양액을 혼 합하여 처리한 경우, 시간이 경과함에 따라 곰팡이의 발생 면 적이 감소하여 6 일차에는 각각 70 과 $90 \%$ 이상이 억제되었다. 특히, P. tolaasii 6264와 HK11의 배양액을 혼합 처리한 경우에 는 2 일차부터 푸른곰팡이의 발생을 $80 \%$ 이상 억제하여 가장 큰 항진균 효과를 보였다. 그러나 P. tolaasii 6264와 HK23을 함께 처리한 경우에는 푸른곰팡이에 대한 항진균 효과가 더디게

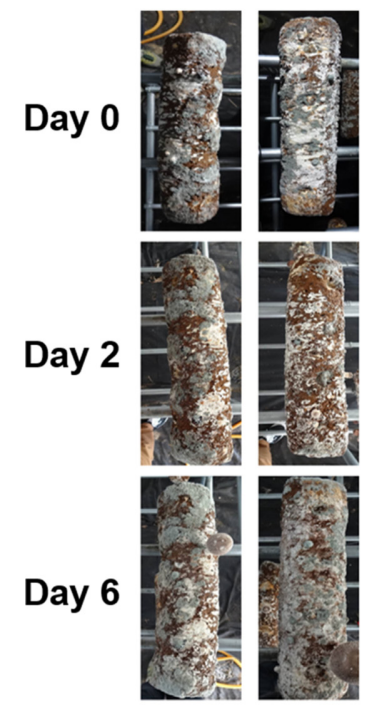

Control

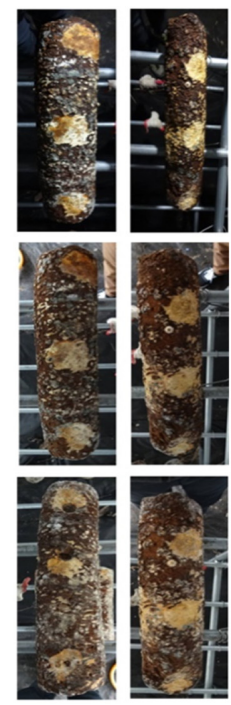

$6264+$ HK2

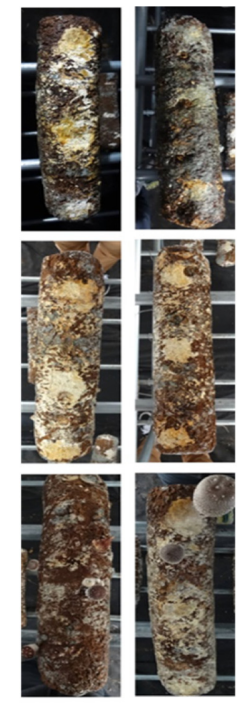

6264+HK11

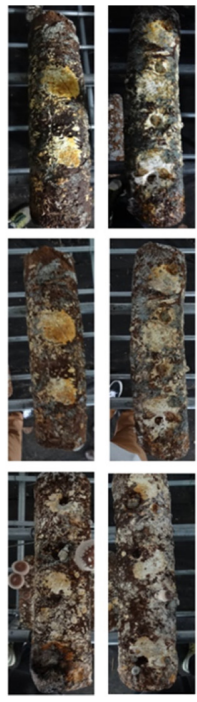

6264+HK23

Fig. 2 Antifungal activities of the mixed culture treatments. Three different combinations of P. tolaasii 6264 and HK2, 6264 and HK11, and 6264 and HK23 were sprayed on the green molds of sawdust media 


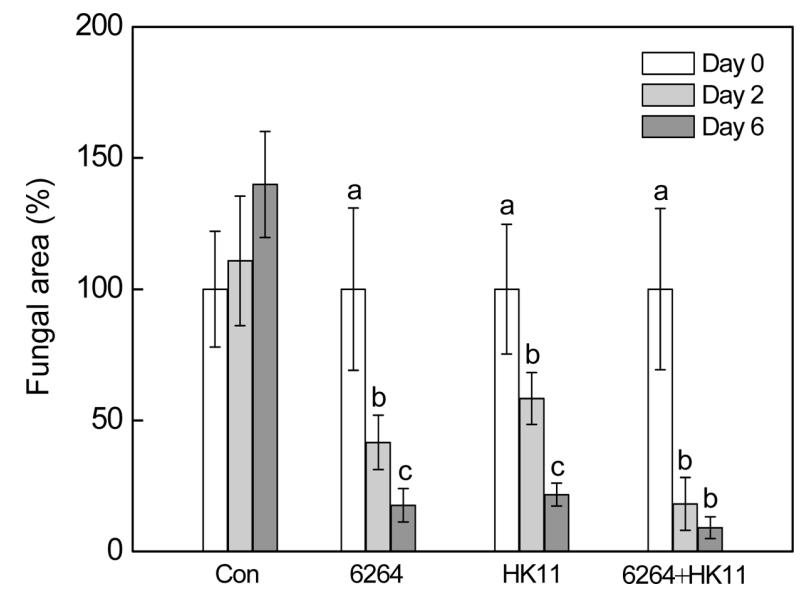

Fig. 4 Antifungal activity increased by the combination of two strains. Comparisons of the fungal growth under the various treatments with the culture extracts of $P$. tolaasii $6264, P$. tolaasii HK11, and P. tolaasii $6264+\mathrm{HK} 11$

일어났으며, 단일 균주 배양액 처리시의 효과보다도 오히려 작 게 나타났다.

\section{단일처리와 혼합처리에 의한 항진균 효과}

균주들의 배양액 혼합처리 실험에서 높은 효과를 보인 P. tolaasii 6264와 HK11 균주에 대하여 두 균주 배양액의 혼합 처리시와 단일 처리시의 항진균 효과를 비교하였다(Fig. 4). P. tolaasii 6264 와 HK11의 배양액을 단일처리한 경우에는 2일차에 $40-60 \%$, 6일차에는 약 75-80\%의 항진균 효과를 보였다. 반면, P. tolaasii 6264와 HK11을 혼합하여 처리하였을 때에는 2일차에서부터 뛰 어난 항진균 효과를 보여 $80 \%$ 이상 푸른곰팡이의 발생을 억제 하였으며, 6 일차에는 $90 \%$ 이상의 항진균 효과를 보였다. 이러한 결과는 항진균 펩티드를 분비하는 균주인 P. tolaasii 6264와 HK11를 단일처리하였을 때보다 두 균주의 배양액을 혼합처리하 였을 때 항진균 효과가 상승함을 보여준다. 각각의 균주배양액 을 혼합처리시 효과가 더욱 상승한다는 사실은 이 두 균주가 생 산하는 항진균 펩티드가 곰팡이의 사멸에 서로 보완적이거나 협 동적으로 작용하여 항진균 효과가 커짐을 의미한다.

\section{다양한 변이주의 항진균 효과}

항진균 효과가 우수한 P. tolaasii HK2, HK11, HK23 균주들의 배양액 조합으로 항진균 효과의 상승작용 여부를 확인하였다 (Fig. 5). P. tolaasii $\mathrm{HK} 2$ 와 $\mathrm{HK} 11, \mathrm{HK} 2$ 와 $\mathrm{HK} 23$ 의 조합은 6 일 경과하였을 때 $70-75 \%$ 까지 푸른곰팡이를 사멸시켰으나 HK2 의 단독 처리와 유사한 수준의 항진균 활성을 보였고, 따라서 이는 $\mathrm{HK} 2$ 의 주된 효과인 것으로 판단된다. 반면, P. tolaasii $\mathrm{HK} 11$ 과 HK23 균주의 조합은 2일차에 약 $75 \%$ 까지 항진균 활 성을 보였으나, 오히려 6 일차에는 약 $50 \%$ 의 억제효과를 보여 시간이 경과함에 따라 항진균 활성이 감소하였다. 이는 각 균 주를 단독 처리하였을 때보다도 낮아 두 균주의 혼합 처리는 푸른곰팡이 억제에는 부적절한 조합으로 판단된다. 이러한 결과 로, 4 종의 P. tolaasii 균주 배양액 조합 중 항진균 효과는 $90 \%$ 이상 푸른곰팡이를 억제한 P. tolaasii 6264와 HK11의 배 양액 조합이 가장 효과적이었으며, 6264 균주를 제외한 균주에

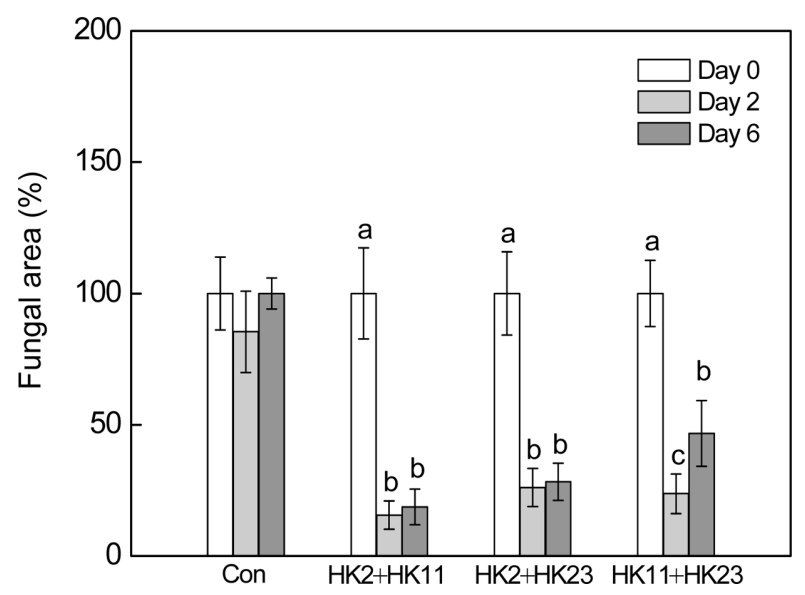

Fig. 5 Antifungal effects of mixed cultures. Cultures with $P$. tolaasii HK2 and HK11, HK2 and HK23, and HK11 and HK23 were obtained

서는 P. tolaasii $\mathrm{HK} 2$ 와 $\mathrm{HK} 11$ 의 혼합 처리가 우수한 푸른곰팡 이 억제 효과를 보였다.

톱밥배지상의 푸른곰팡이 생육면적은 대조구의 경우 배양시 간에 따라 계속 증가하였으나, 항진균 펩티드를 생산하는 균주 의 배양액을 단일 처리하거나 두 균주 이상을 혼합처리하였을 때는 최대 80-90\%까지 감소하였다. 표고버섯 배지에서 푸른곰 팡이 억제효과를 정량적으로 측정하는 방법은 현재 알려지지 않 았다. 본 실험에서는 톱밥배지에 발생한 푸른곰팡이의 양을 측 정하기 위하여 '색상선택법'을 고안하여 이용하였다(Lee 등, 2017). 이 방법은 시간에 따라 변하는 곰팡이의 생육면적을 측 정하기 위한 간이방법으로, 푸른곰팡이의 발생부위와 발생면적 평가에는 적절한 방법으로 판단되나, 이 방법의 정량성을 높이 기 위해서는 푸른곰팡이 포자의 양이나 균사의 양을 측정하는 방법 등이 개발되어 상호보완적으로 이용되어야 할 것이다.

푸른곰팡이병 방제효과를 높이기 위한 혼합 균주 배양액 처 리에서 P. tolaasii 6264의 경우에는 다른 균주배양액과 혼합처 리하였을 때 상승효과를 보였으며, 특히 P. tolaasii HK11와 혼 합 처리시에는 푸른곰팡이의 발생을 $90 \%$ 이상 억제하였고 이 후 추가적인 균사성장이 전혀 관측되지 않아 완벽한 항진균 효 과를 보였다. 그러나 다른 균주의 경우에는 혼합시에 상승효과 가 거의 나타나지 않고 단독 처리시와 유사하거나 이보다 못한 수준의 항진균 효과를 보였다. 이 결과로 미루어 보았을 때, 혼 합에 따른 항진균 활성의 상승효과는 두 균주의 펩티드가 상호 보완적인 작용기작을 가질 때 나타나는 것으로 생각되며, 상호 작용으로 펩티드 침전을 형성하거나 할 때는 오히려 활성이 떨 어질 것으로 예상된다. 혼합 처리에 의한 상승효과는 여러 균 주에서 보고되었다. Candida 종이나 Cryptococcus 종을 방제하 기 위하여 glabridin과 fluconazole을 혼합 처리한 경우에 단일 처리의 경우보다 월등히 좋은 방제효과를 보였으며(Liu 등, 2014), Saravanakumar 등(2016)은 키틴용해성 효소(chitinolytic enzyme)를 분비하는 Trichoderma 종과 Gliocladium 종을 혼합 처리하였을 때 병원성 진균을 사멸시키는 효과가 크게 향상된 다고 밝혔다.

톨라신과 유사체 펩티드류는 모두 18 개의 아미노산으로 구성 되어 $2 \mathrm{kDa}$ 내외의 분자량을 갖고 있다(Nutkins 등, 1991). 이 
들 중 서로 상보적인 작용으로 상승작용을 갖거나 침전되어 활 성이 감소하는 등의 특성은 아직 밝혀진 바 없다. 본 연구에서 관측된 상승작용의 기작을 연구하기 위해서는 각 균주가 생산 하는 펩티드의 종류와 조합을 밝혀야 할 것이다. 항진균성 펩 티드인 톨라신의 경우에는 이미 여러 연구에서 많은 유사체 (analogue)가 보고되었다. 선행 연구에서 P. tolaasii 6264가 분 비하는 톨라신 유사 펩티드가 밝혀졌으며(Cho 등, 2007a), 이 유사체들은 P. tolaasii Paine 균주가 생산하는 tolaasin-I 및 tolaasin-II임이 확인되었다. 이를 토대로 하여 여러 균주들의 펩 티드 조성을 확인하여 항진균 활성과 비교한다면, 혼합처리시 펩티드의 종류와 조합에 따른 항진균 활성의 특성변화를 예측 하는 것이 가능할 것이다.

\section{초 록}

표고버섯(Lentinus edodes)은 원목이나 톱밥배지를 사용하여 재 배한다. 이 배지에 푸른곰팡이(Trichoderma)가 감염되면 표고버 섯의 생장을 크게 억제한다. 버섯은 신선식품이기 때문에 푸른 곰팡이를 방제하기 위한 항생제와 화학약품의 사용은 허용되지 않는다. Pseudomonas tolaasii에 의해 분비되는 펩티드 독소인 톨라신과 톨라신 유사체들은 항진균 활성을 가져 푸른곰팡이병 방제에 성공적이었다. 푸른곰팡이 Trichoderma harzianum $\mathrm{H} 1$ 에 톨라신 펩티드를 처리하였을 때 곰팡이의 성장은 효과적으로 억 제되었고, 실제 톱밥배지에서 균주 배양액을 푸른곰팡이 균사에 분사하였을 때, 균사 성장은 완벽하게 억제되었다. 특히, $P$. tolaasii 6264와 HK11 균주의 배양 추출액을 혼합하여 처리하 였을 때에 항진균 활성이 크게 증가하였다. 따라서 이러한 균 주들과 펩티드 독소들은 푸른곰팡이의 성장을 억제할 수 있고, 표고버섯 재배에서 푸른곰팡이병을 방제하기 위한 좋은 후보가 될 수 있다.

Keywords 상승효과 · 표고버섯 - 푸른곰팡이병 - 항진균성 펩 티드· Trichoderma harzianum

감사의 글 이 논문은 2016년도 충북대학교 연구년제 사업의 연구비 지원에 의하여 연구되었으며, 색상선택법 개발에 도움을 주신 빅토리컴퍼니 김지은 팀장께 감사드립니다.

\section{References}

Ait-Lahsen H, Soler A, Rey M, de La Cruz J, Monte E, Llobell A (2001) An antifungal exo-alpha-1,3-glucanase (AGN 13.1) from the biocontrol fungus Trichoderma harzianum. Appl Environ Microbiol 67: 5833-5839 Brian P, Hemming H (1945) Gliotoxin, a fungistatic metabolic product of Trichoderma viride. Ann Appl Biol 32: 214-220

Chihara G, Hamuro J, Maeda Y, Arai Y, Fukuoka F (1970) Fractionation and purification of the polysaccharides with marked antitumor activity, especially lentinan, from Lentinus edodes (Berk.) Sing. (an edible mushroom). Cancer Res 30: 2776-2781

Cho KH, Kim ST, Kim YK (2007a) Purification of a pore-forming peptide toxin, tolaasin, produced by Pseudomonas tolaasii 6264. J Biochem Mol Biol 40: 113-118

Cho KH, Park KS, Kim YK (2000) Hemolytic properties of tolaasin causing the brown blotch disease on oyster mushroom. J Korean Soc Appl Biol Chem 43: 190-195

Cho KH, Shin DS, Kim YK (2007b) Effects of mushroom extracts on the growth and pathogenicity of Pseudomonas tolaasii, a pathogenic bacterium of brown blotch disease. J Agr Sci Chungbuk Nat'l Univ 23: $133-142$

Fujii T, Maeda H, Suzuki F, Ishida N (1978) Isolation and characterization of a new antitumor polysaccharide, KS-2, extracted from culture mycelia of Lentinus edodes. J Antibiot 31: 1079-1090

Kim JW, Kim KH, Kang HJ (1994) Studies on the pathogenic Pseudomonas causing bacterial disease of cultivated mushroom in Korea: 1 . On the causal organisms of the rots of Agaricus bisporus, Pleurotus ostreatus and Lentinus edodes. Kor J Plant Pathol 10: 197-210

Komon-Zelazowska M, Bissett J, Zafari D, Hatvani L, Manczinger L, Woo S, Lorito M, Kredics L, Kubicek CP, Druzhinina IS (2007) Genetically closely related but phenotypically divergent Trichoderma species cause green mold disease in oyster mushroom farms worldwide. Appl Environ Microbiol 73: 7415-7426

Korea Rural Economic Institute (2014) http://krei.re.kr/ak_library/uploads/ info/observe upload/FS201208.pdf. Accessed 12 November 2014

Lee HJ, Yun YB, Huh JH, Kim YK (2017) Suppression of green mold disease on oak mushroom cultivation by antifungal peptides. J Appl Biol Chem 60: $149-153$

Lee YS, Kim J, Lee SG, Oh E, Shin SC, Park IK (2009) Effects of plant essential oils and components from Oriental sweetgum (Liquidambar orientalis) on growth and morphogenesis of three phytopathogenic fungi. Pestic Biochem Phys 93: 138-143

Liu W, Li LP, Zhang JD, Li Q, Shen H, Chen SM, He LJ, Yan L, Xu GT, An MM, Jiang YY (2014) Synergic antifungal effect of glabridin and fluconazole. PLoS ONE 9: e103442. Doi: 10.1371/journal.pone.0103442 Nutkins JC, Mortishire-Smith RJ, Packman LC, Brodey CL, Rainey PB, Johnstone K, Williams DH (1991) Structure determination of tolaasin, an extracellular lipodepsipeptide produced by the mushroom pathogen, Pseudomonas tolaasii Paine. J Am Chem Soc 113: 2621-2627

Ota S (1984) Shiitake (Lentinus edodes). New Food Industry 26: 49

Saravanakumar K, Yu C, Dou K, Wang M, Li Y, Chen J (2016) Synergistic effect of Trichoderma-derived antifungal metabolites and cell wall degrading enzymes on enhanced biocontrol of Fusarium oxysporum f. sp. cucumerinum. Biological Control 94: 37-46

Seaby D (1998) Trichoderma as a weed mould or pathogen in mushroom cultivation. Trichoderma and Gliocladium CRC Press, London 